\title{
A high-affinity peptide ligand targeting syntenin inhibits glioblasto-
}

ma

Linda M. Haugaard-Kedström ${ }^{1 * \dagger}+$, Louise Strandberg Clemmensen ${ }^{1} \uparrow$, Vita Sereikaité ${ }^{1} \uparrow$, Zeyu $\operatorname{Jin}^{2} \uparrow$, Eduardo F. A. Fernandes ${ }^{1}$, Bianca Wind ${ }^{1}$, Flor Abalde-Gil ${ }^{1}$, Jan Daberger ${ }^{1}$, Raphael Leblanc ${ }^{3}$, Antonio L. Egea-Jimenez ${ }^{3,4}$, Marte Albrigtsen ${ }^{5}$, Kamilla. E. Jensen ${ }^{6}$, Diana A. Morante ${ }^{6}$, Thomas M. T. Jensen ${ }^{1}$, Ylva Ivarsson ${ }^{7}$, Renaud Vincentelli ${ }^{8}$, Petra Hamerlik ${ }^{6}$, Jeanette Hammer Andersen ${ }^{5}$, Pascale Zimmermann $^{3,4}$, Weontae Lee ${ }^{2 *}$ and Kristian Strømgaard ${ }^{1 *}$

${ }^{1}$ Center for Biopharmaceuticals, Department of Drug Design and Pharmacology, University of Copenhagen, Universitetsparken 2, 2100 Copenhagen, Denmark.

${ }^{2}$ Department of Biochemistry, College of Life Science and Biotechnology, Yonsei University, Seoul 120-749, Korea.

${ }^{3}$ Centre de Recherche en Cancérologie de Marseille (CRCM), Inserm, U1068-CNRS UMR7258, Aix-Marseille Université, Institut Paoli-Calmettes, 13009 Marseille, France.

${ }^{4}$ Department of Human Genetics, KU Leuven, ON1 Herestraat 49 Box 602, B-3000 Leuven, Belgium.

${ }^{5}$ Marbio, UiT-The Artic University of Norway, N-9037 Tromsø, Norway.

${ }^{6}$ Brain Tumor Biology Group, Danish Cancer Society Research Center, Strandboulevarden 49, 2100 Copenhagen, Denmark.

${ }^{7}$ Department of Chemistry-BMC, Uppsala University, SE-751 23 Uppsala, Sweden.

${ }^{8}$ Unité Mixte de Recherche (UMR) 7257, Centre National de la Recherche Scientifique (CNRS), Aix-Marseille Université, Architecture et Fonction des Macromolécules Biologiques (AFMB), Campus de Luminy, 163 Avenue de Luminy, 13288, Marseille Cedex 09, France.

KEYWORDS: syntenin, peptide inhibitor, PDZ domain, structure-activity relationship

ABSTRACT: Despite the recent advances in cancer therapeutics, highly aggressive cancer forms, such as glioblastoma (GBM), have still very low survival rates. The intracellular scaffold protein syntenin, comprising two PDZ domains, has emerged as a novel therapeutic target in highly malignant phenotypes including GBM. Here, we report the development of a novel, highly potent and metabolically stable peptide inhibitor of syntenin, KSL-128114, which binds the PDZ1 domain of syntenin with nanomolar affinity. KSL-128114 is resistant towards degradation in human plasma and mouse hepatic microsomes, and displays a global PDZ domain selectivity for syntenin. An X-ray crystal structure reveals that KSL-128114 interacts with syntenin PDZ1 in an extended noncanonical binding mode. Treatment with KSL-128114 showed an inhibitory effect on primary GBM cell viability and significantly extends survival time in a patient-derived xenograft mouse model. Thus, KSL-128114 is a novel promising candidate with therapeutic potential for highly aggressive tumors, such as GBM.

\section{INTRODUCTION}

Protein-protein interactions (PPIs) are vital for most biochemical and cellular processes and offer attractive opportunities for therapeutic intervention. In particular, disrupting intracellular signalling transduction via inhibition of scaffolding proteins comprising postsynaptic density protein-95 (PSD-95)/discs-large/zona occludens-1 (PDZ) domains has gained considerable attention. ${ }^{1}$ The human proteome contains $266 \mathrm{PDZ}$ domains in 152 proteins and is one of the largest class of protein domains facilitating PPIs. ${ }^{2}$ The intracellular scaffold protein syntenin, also known as melanoma differentiation associated gene-9 (mda-9) or syntenin-1, comprise two PDZ domains, flanked by intrinsically disordered N- and C-terminal regions. ${ }^{3-4}$ The primary function of syntenin is to transduce and propagate extracellular stimuli via transmembrane proteins and receptors, such as the syndecans, Frizzled 7 or CD63 (Figure 1), by mediating the assembly of intracellular multimeric signaling complexes. ${ }^{5}$ Additionally, numerous binding partners and effectors downstream of syntenin have been identified including: c-Src, focal adhesion kinase (FAK), p38 mitogen-activated protein kinase (MAPK) and nuclear factor-kappa B (NF-KB). ${ }^{5}$ Thus, syntenin dependent signalling pathways regulate a plethora of molecular pathways, which directly or indirectly facilitate cell invasion. This is reflected in the therapeutic relevance of syntenin as a promoter of cancer cell migration and metastasis. ${ }^{5}$ A key step in cancer cell invasion is the degradation of extracellular matrix via matrix metalloproteinases (MMPs). ${ }^{6}$ Syntenin promotes the expression of MMP2 by activating the expression of the transcription factor NF-KB through a c- 
Src dependent pathway in glioblastoma $(\mathrm{GBM})^{7}$ and melanoma. ${ }^{8}$ In addition, the syntenin-syndecan-ALIX signalling pathway has a vital role in the formation of endosomal intraluminal vesicles, which are released into the extracellular space as exosomes. ${ }^{9-10}$ Exosomes can regulate tumorigenesis by transferring signalling components to surrounding cells to induce remodelling of the extracellular matrix and promote angiogenesis and tumour cell proliferation. ${ }^{11-15}$ Noteworthy, syntenin was recently shown to be mandatory for the activity of the oncogene Src in exosomal cell-to-cell communication. ${ }^{15}$ In several cancer types, including melanoma, GBM, breast cancer and urothelial cell cancer, there is a direct correlation between increased syntenin expression and the advancement of tumour grades. ${ }^{5}$ Thus, syntenin acts as a facilitator of both intracellular and extracellular pathways of cancer cell invasion and progression and therefore serves as an attractive and novel therapeutic intervention point in cancer.

Here, we developed a high affinity peptide-based inhibitor of syntenin, KSL-128018, and explored its therapeutic potential. The optimized peptide binds in a non-canonical PDZ binding mode, as demonstrated by a co-crystal X-ray structure of KSL-128018 and PDZ1 of syntenin and show a preference towards syntenin PDZ1 in a global selectivity screen of 255 PDZ domains. The peptide was further developed to comprise cell permeable properties and showed improved in vitro plasma and microsomal stability. Finally, we demonstrated that by applying this competitive inhibitor of syntenin, inhibition of primary GBM cell proliferation in vitro and remarkably prolonged survival from 25 to 45 days in a patient-derived xenograft GBM mouse model was achieved.

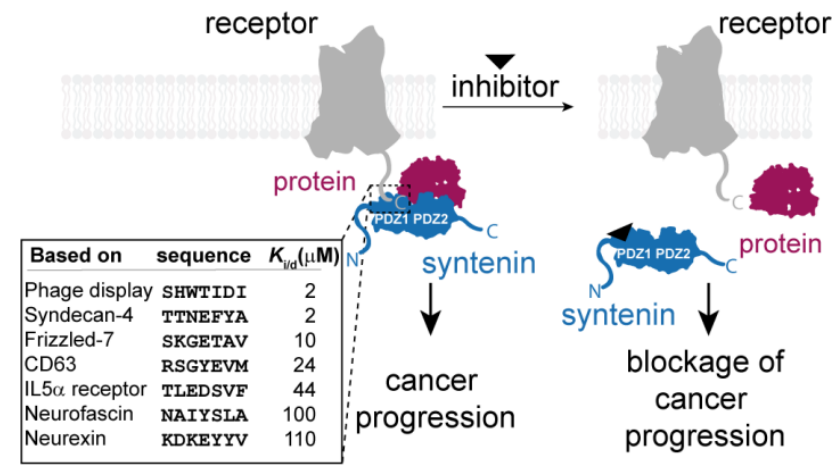

Figure 1. Schematic illustration of syntenin dependent protein-protein interactions. Syntenin (blue) interacts with the extreme C-terminal of multiple interactions partners (grey and red) via its two PDZ domains. Several of these proteinprotein interactions mediate and promote cancer progression. By applying a syntenin inhibitor (black triangle) and subsequently uncouple the protein complex, the connection between receptor activation and cancer progression, is inhibited.

\section{RESULTS}

Design and characterization of novel high affinity peptide inhibitors of syntenin. Recently, using phage display technology, a heptameric peptide $\left({ }^{-6} \mathrm{SHWTIDI}^{0}\right)$ was identified to bind to syntenin with low $\mu \mathrm{M}$ affinity. ${ }^{16}$ Here, we aimed to optimize the reported inhibitor addressing its drug-like properties, such as affinity, stability, toxicity and cell permeability. First, we determined the inhibitory binding constant $\left(K_{\mathrm{i}}\right)$ of a phage display peptide in a fluorescence polarization (FP) assay to be $2.1 \mu \mathrm{M}$ towards syntenin PDZ1-2 tandem. Second, to improve affinity and stability for this peptide, a range of modifications was introduced into the peptide, including N-terminal truncations, Ala, D-amino acid, single proteinogenic and non-proteinogenic amino acid substitutions (Figure 2A,B). This provided several insights, including the importance of the Trp side chain at position -4 , which is not included in the canonical peptide-PDZ binding interface. Generally, L-amino acids were preferred over the corresponding D-amino acids which were only allowed in positions -5 and -6 . The importance of hydrophobic side chain interactions at positions $0,-2$ and -3 was addressed by incorporating either proteinogenic or non-proteinogenic amino acids. Several hydrophobic side chains could be accommodated at these positions resulting in no or minor effects on the affinity with $K_{\mathrm{i}}$ values ranging from $0.7-15.3 \mu \mathrm{M}$ (Figure 2C and Table S1). Gratifyingly, by combining a tert-butyl glycine (Tle) at position -3 with a cyclohexyl glycine (Chg) at position -2, providing SHW(Tle)(Chg)DI (KSL-128018), a significant synergistic affinity effect was achieved. Peptide KSL-128018 had a 50-fold increase in affinity corresponding to a $K_{\mathrm{i}}$ value of $40 \mathrm{nM}$ (Figure $2 \mathrm{D}$ and Table $\mathrm{S} 1$ ). The $K_{\mathrm{d}}$ of the TAMRA-labelled KSL-128018 peptide to syntenin PDZ1-2 was determined to $30 \mathrm{nM}$ (Table S1). This is to the best of our knowledge, the most potent monomeric inhibitor reported for any PDZ domain. To obtain further insight into the binding kinetics, we prepared a biotin labelled version of peptide KSL-128018, biotin-PEG2-SHW(Tle)(Chg)DI, and analysed this peptide by surface plasmon resonance (SPR). The apparent $K_{\mathrm{d}}$ value towards PDZ1-2 of syntenin was determined to $170 \mathrm{nM}$ (Figure $\mathrm{S} 1$ ), which is consistent with the $K_{\mathrm{i}}$ value of $190 \mathrm{nM}$ determined by FP (Table S1). The apparent association $\left(k_{\text {on }}\right)$ and dissociation rate constant $\left(k_{\text {off }}\right)$ was determined to $3.1 \times 10^{5} \mathrm{M}^{-1} \mathrm{~s}^{-1}$ and $0.05 \mathrm{~s}^{-1}$, respectively, which corresponds to both a fast association and dissociation with the protein. Additionally, using SPR, the selectivity of this peptide towards PDZ1-2 of syntenin over syntenin-2 was also addressed and showed that KSL-128018 is 440-fold more selective for syntenin (Figure S1). In order to make peptide KSL-128018 cell-permeable, five different CPP tags, including TAT (amino acid sequence 47-57) and polyArg8, ${ }^{17-19}$ (peptides 1-4) (Figure 2E and Table S2), were introduced into the N-terminal of peptide KSL-128018 preserving a free $\mathrm{C}$-terminal carboxylate which is critical for binding. The addition of CPP tags only had a minor effect on affinity, resulting in $K_{\mathrm{i}}$ values ranging from $250-452 \mathrm{nM}$ (Figure 2E and Table 
a

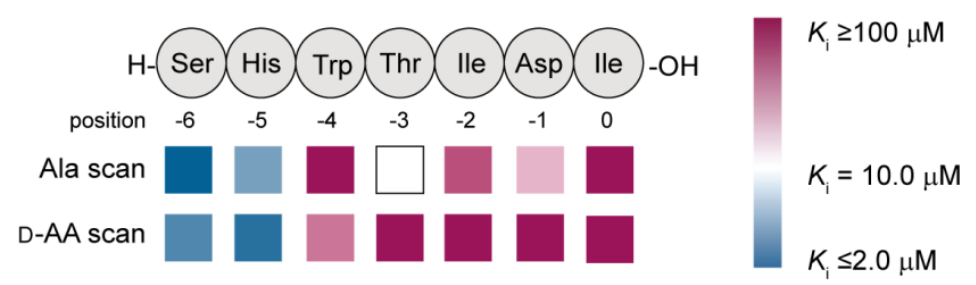

b
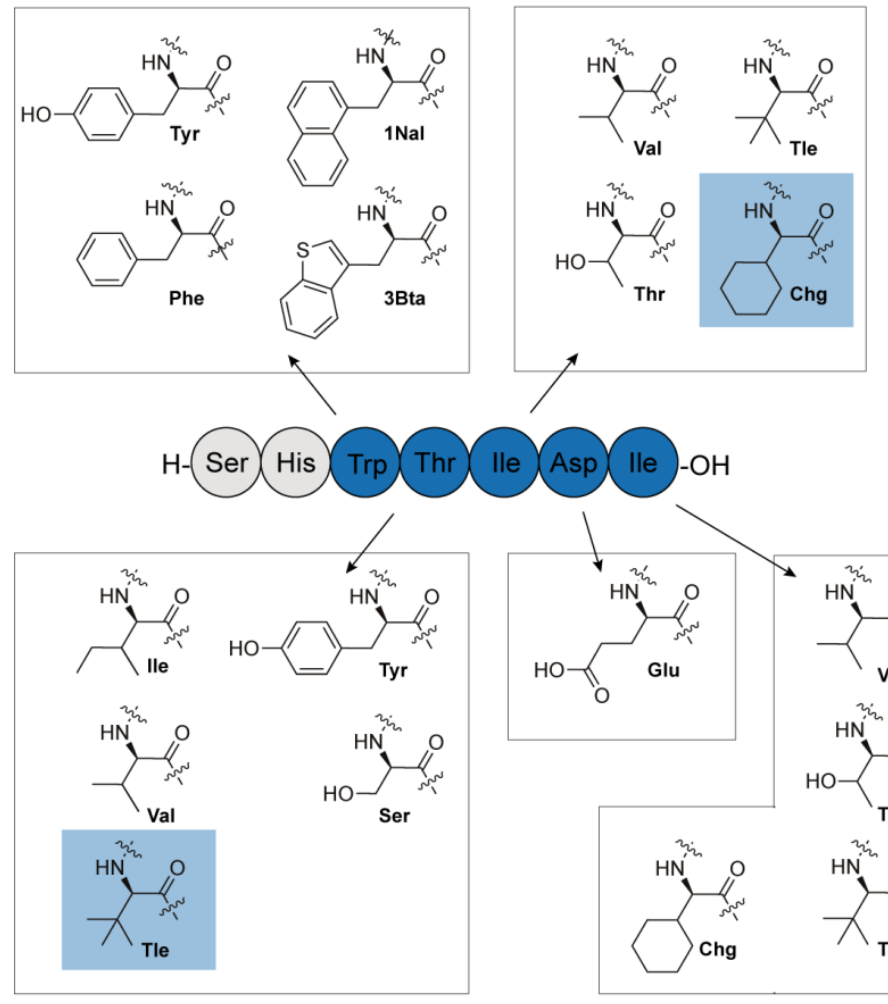

e

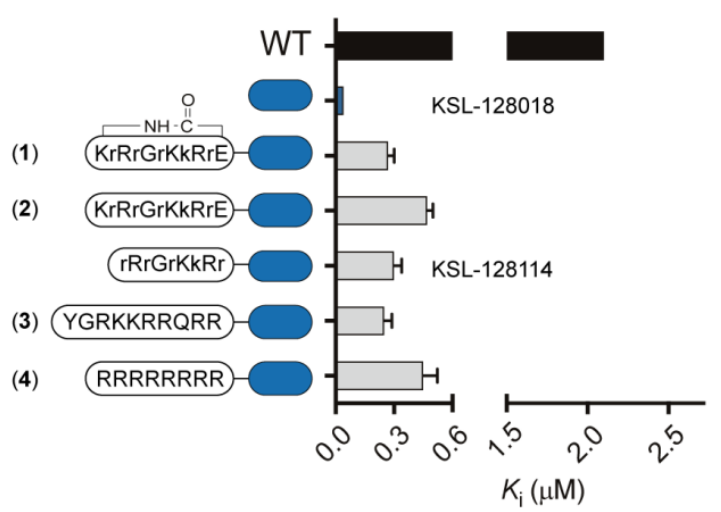

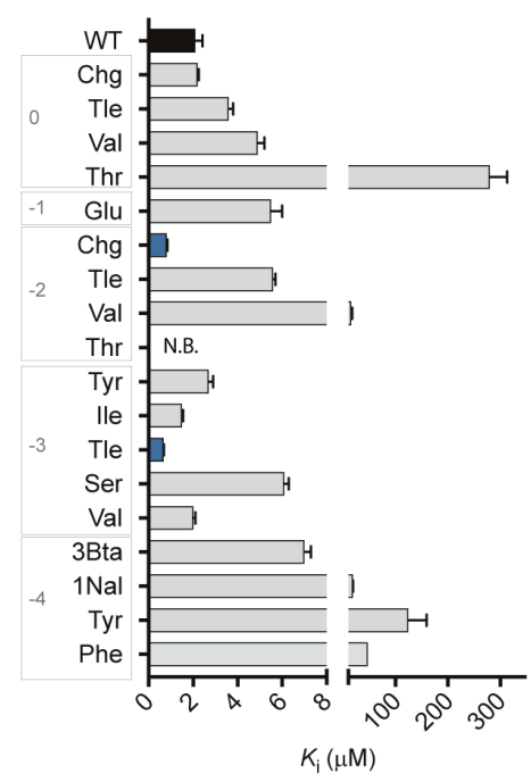

d

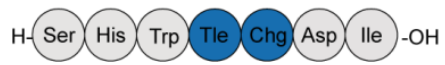

Figure 2. Structure-activity relationship (SAR) study and characterisation of in vitro metabolic stability. (A) Sequence of the phage display derived parent peptide referred to as WT and heat-map of Ala and D-amino acid scan. The colours represent the binding affinity to syntenin PDZ1-2 determined by fluorescent polarisation (FP). (B) Structures of the amino acid side chains introduced as single substitutions. Structures highlighted in a blue box represent the substitutions generating an improved affinity compared to the parent peptide. $(\mathbf{C})$ Binding affinities $\left(K_{\mathrm{i}}\right)$ for peptides comprising a single substitution or $(\mathbf{D})$ double substitutions. (E) Sequences of cell-penetrating peptides and its binding affinities towards syntenin PDZ1-2. Blue box represents KSL-128018. (F) In vitro stability of selected cell-penetrating peptides in human plasma and $(\mathbf{G})$ hepatic mouse microsomes over time. Data is presented as mean \pm SEM, $\mathrm{n} \geq 3$. N.B. indicates a $K_{\mathrm{i}}>500 \mu \mathrm{M}$.

$\mathrm{X}$-ray crystal structure and amide-to-ester mutations reveal a non-canonical binding mode. To obtain molecular insight into the binding mode of peptide KSL-128018, an Xray co-crystal structure of the syntenin PDZ1 domain in complex with KSL-128018 was determined at a resolution of 1.86 A (PDB ID: 6AK2). KSL-128018 binds to the canonical PDZ binding site located between the $\beta 2$ sheet and $\alpha 2$ helix. (Figure 3A,B and Figure S2). In the canonical binding mode 


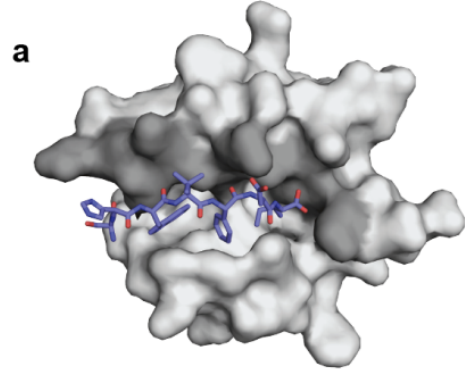

d

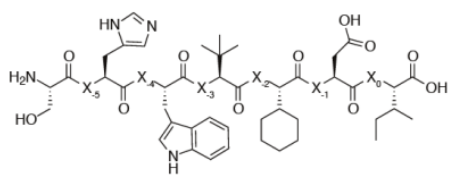

b

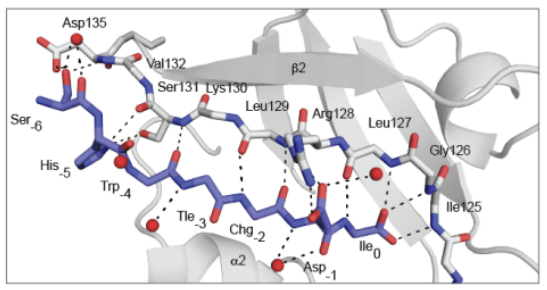

$\mathbf{f}$

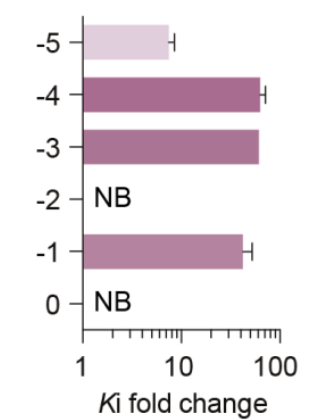

c
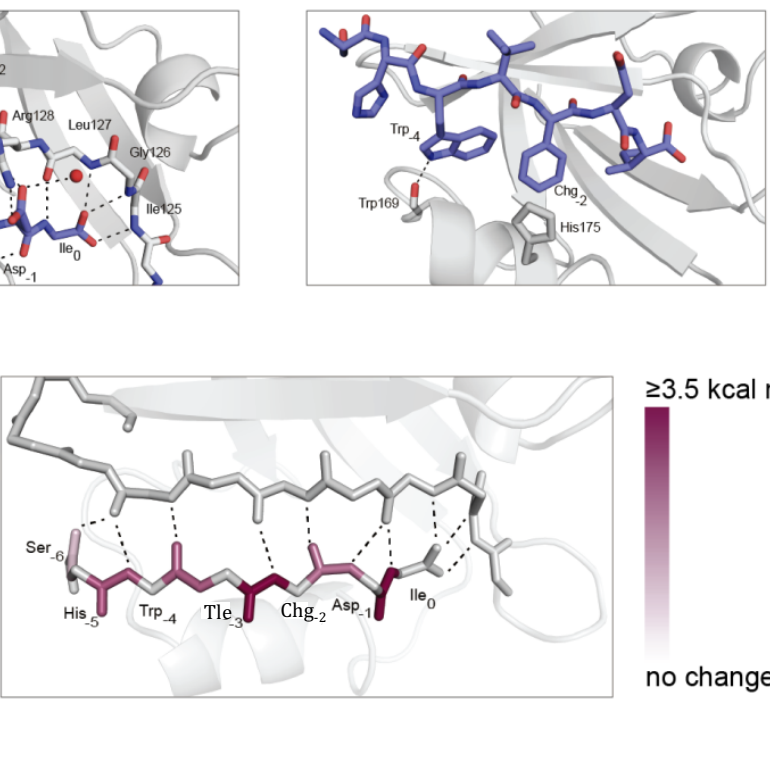

$\geq 3.5 \mathrm{kcal} \mathrm{mol}^{-1}$

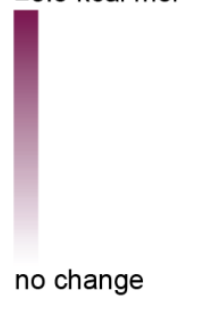

Figure 3. Molecular mapping of the KSL-128018/syntenin interaction. (A) X-ray crystal structure of syntenin PDZ1 in complex with KSL-128018 (PDB 6AK2). (B) Zoom-in of the syntenin binding site. KSL-128018 (blue sticks) forms multiple hydrogen bond interactions (black dotted lines) to syntenin (grey). Five water molecules (red spheres) are coordinated in the binding pocket. (C) The side chain of Trp-4 in KSL-128018 forms hydrogen bond interaction with the backbone of Trp169 and Chg-2 forms a $\pi-\pi$ interaction with His175 in syntenin PDZ1. (D) Structural overview of KSL-128018. X indicates position of single amide-to-ester backbone substitution. (E) Fold change in affinity of depsipeptides compared to KSL-128018. Number indicates the position of amide-to-ester substitution. (F) Heat map of the relative binding energy, $\Delta \Delta \mathrm{G}$, of the amide-to-ester backbone substitutions.

C-terminal carboxylate moiety, are the primary contributors of binding. ${ }^{20-22}$ However, KSL-128018 demonstrates a more complex binding profile, involving significant contributions from amino acid side chains in position $0,-1,-2$ and -4 (Figure S2C). The side chains of Ile127, Arg128, Leu129, Ser131, Val132, Asp133, which are located in the $\beta 2$ strand and His 175 in $\alpha 2$ helix of syntenin are key residues for the molecular interaction with KSL-128018 (Figure 3C and Figure S2C). A number of hydrogen bond interactions between PDZ1 and peptide KSL-128018 were identified, including side chain-side chain interaction between Arg128 and Asp-1, side chain-backbone interaction between Trp-4 and Trp169, backbone-backbone interactions between amino acids in position 0 and -2 to Leu127, Leu129, respectively, and the C-terminal carboxylate to the backbone of Ile125, Gly126 and Leu127 (Figure 3B,F). Interestingly, several water molecules were observed in the binding site and mediate interactions between the peptide ligand and the protein through hydrogen bonds (Figure 3B and Figure S2D), thus stabilizing the protein-inhibitor complex. To further assess the importance of the hydrogen bonding network, we systematically introduced amide-to-ester substitutions into the backbone of peptide KSL-128018. An amide-to-ester substitution removes a NH hydrogen bond and reduces the hydrogen bond acceptor capacity of the carbonyl by ca. $50 \%{ }^{23} \mathrm{We}$ synthesized the six depsipeptide analogues (Figure 3D), where each backbone amide bond in peptide KSL-128018 was substituted with an ester bond. Subsequently the determined binding affinities of depsipeptides to syntenin revealed that an ester bond between either amino acids in position 0 and -1 or -2 and -3 led to reduction of binding affinity by $>300$-fold with $K_{\mathrm{i}}$ values $>30 \mu \mathrm{M}$. Introduction of an ester bond between amino acids -1 and $-2,-3$ and -4 , and 4 and -5 led to a decrease in affinity by $20-25$ fold (Figure $3 \mathrm{E}$ and Table S2), which is consistent with hydrogen bonding network shown in the X-ray crystal structure (Figure $3 \mathrm{~B}, \mathrm{~F})$. In summary, an interplay between the C-terminal carboxylate, side chains of amino acids in position $0,-1,-2$ and -4 and the backbone amide bonds between amino acids $0,-1$ and $-2,-3$ are the primary determinants for the very high affinity of peptide KSL-128018 to syntenin.

Inhibitors show global preference for syntenin and ability to pull-down syntenin from brain lysate. PDZ domains are known for being capable of binding to several different peptide ligands, ${ }^{21}$ thus the selectivity profile of biotinylated KSL-128018 was assessed by screening 255 single human PDZ domains by the hold-up assay. ${ }^{24}$ Gratifyingly, the highest affinity for this peptide among the 255 PDZ domains was towards syntenin PDZ1 (binding intensity $(\mathrm{BI})=0.96)$ (Figure S3A). No affinity for syntenin PDZ2 was detected and thus highlighting the preference for PDZ1. Additional binding partners were detected, albeit with lower affinity (Figure $\mathrm{S} 3 \mathrm{~A}$ ). The robustness of the hold-up assay was validated by comparing BI values obtained for selected PDZ domains from the PDZome screen with the corresponding $K_{\mathrm{d}}$ values obtained by FP assays (Figure S3B). The correlation coefficient for the low affinity binders $\left(K_{\mathrm{d}} \leq 1 \mu \mathrm{M}\right)$ was determined to $\mathrm{r}=0.78$, which is in line with previously reported data $(\mathrm{r}=$ $0.76) .^{24}$ 
a

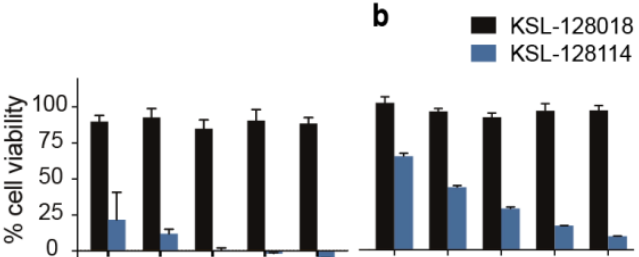

C

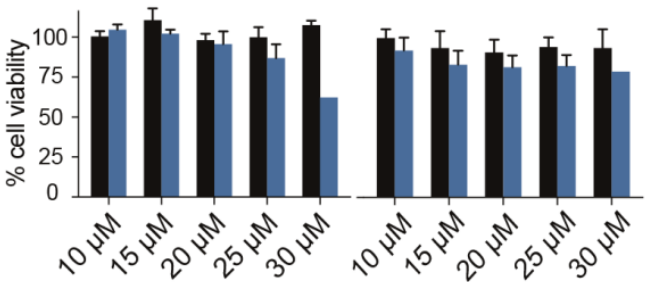

e Ce-Rab5Q79L
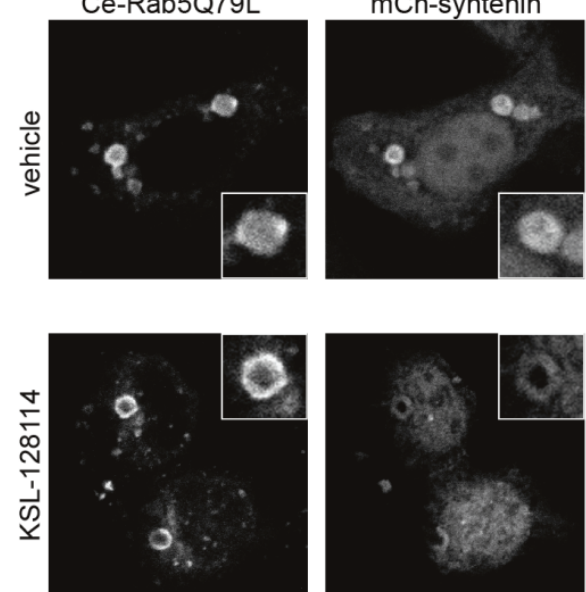

g

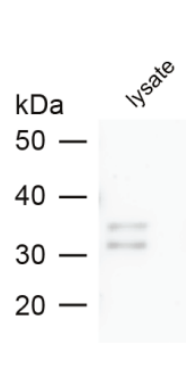

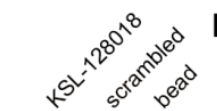

h

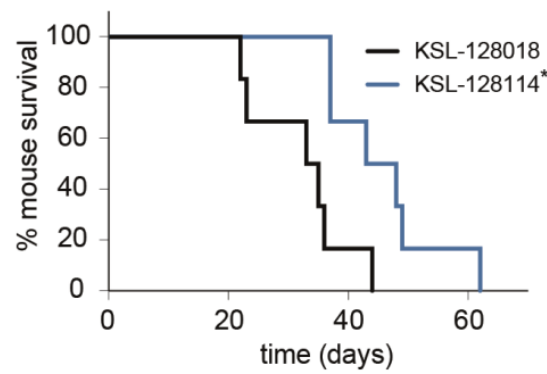

mCh-syntenin
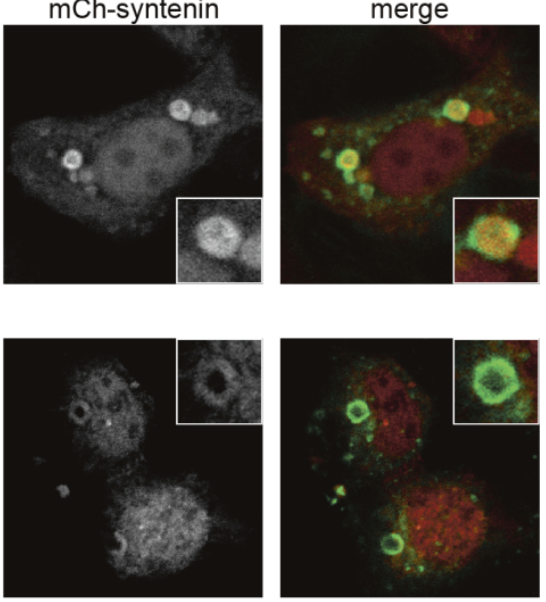

i
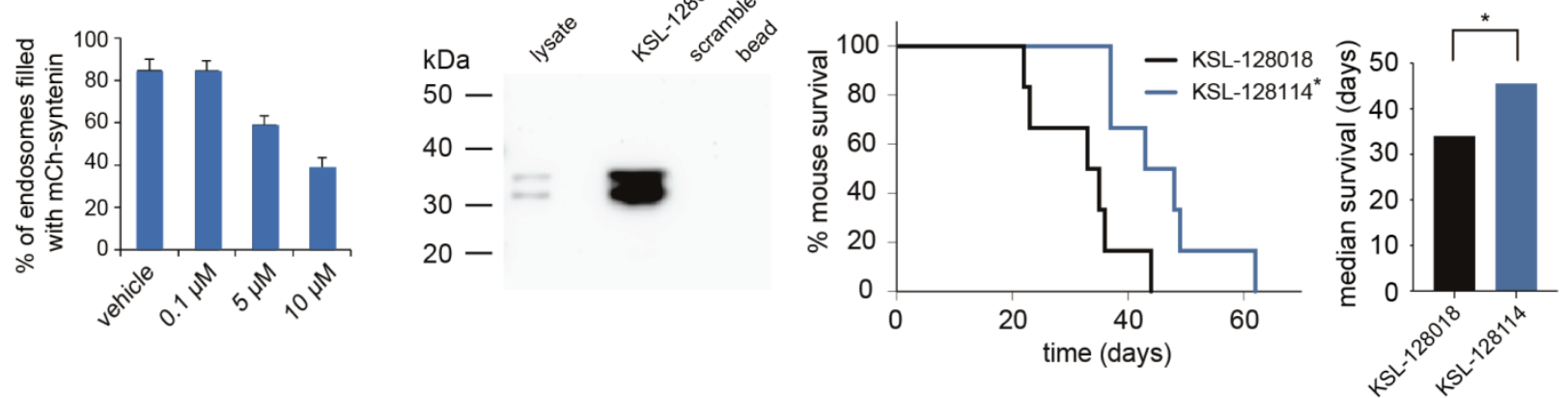

Figure 4. In vitro and in vivo characterisation of KSL-128114. (A) Cell viability of A2058 melanoma cells, (B) patient-derived glioblastoma (GBM) cells, (C) MCF-7 breast cancer cells and (D) HT29 colon adenomcarcinoma cells treated with increasing concentrations of peptides KSL-128018 (black) or KSL-128114 (blue) for $72 \mathrm{~h}$. Data is presented as mean $\pm \mathrm{SD}, \mathrm{n} \geq 3$. (E) Intraluminal budding of mCherrysyntenin filled endosomes. Representative confocal micrographs of MCF-7 cells co-transfected with wild-type mCherry-syntenin (mChSynt; red in merge) and Cerulean-Rab5Q79L (Ce-Rab5Q79L; blue in merge) and treated with $10 \mu \mathrm{M}$ of KSL-128114 or vehicle. (F) Quantification of the number of Ce-Rab5Q79L endosomes filled with mCherry-syntenin after treatment with $0.1,5$ and $10 \mu \mathrm{M}$ of KSL-128114 or vehicle $(0.01 \%$ DMSO in sterilized water) for 24 hours. Data is presented as mean \pm SD. Two independent experiments were performed and at least 40 RAB5(Q79L) endosomes were examined in each experiment. (G) KSL-128018 can pull-down syntenin from brain lysate. Analogues of peptide KSL-128018 or the scrambled negative control peptide, bearing an N-terminal Cys as chemical handle, was immobilised using epoxy reactive resin and used to pull-down syntenin from whole mouse brain lysate. Representative Western blot analysis verified the identity of syntenin. Two independent experiments were performed using brain lysate from two individual mice. (H) KaplanMeier survival curves for mice intracranially injected with patient-derived GBM cells pre-treated with KSL-128018 (black) or KSL128114 (blue) and (I) median survival. $\mathrm{n}=6,{ }^{*} \mathrm{p}<0.05$.

Detection of ligand-protein interaction in vitro does not necessary translate into target engagement in a complex cellular environment. Thus, we examined if an immobilized version of peptide KSL-128018 could be used to enrich syntenin from mouse brain lysate and subsequently validate the results from the PDZome screen. Satisfyingly, peptide KSL-128018, but not a non-binding scrambled control peptide, could recover and enrich full length syntenin from the complex whole brain cellular mixture (Figure 4G).

In vitro metabolic stability. Peptide ligands are generally susceptible to proteolytic degradation in biological fluids, which is a major challenge for peptide-based drugs. ${ }^{25} \mathrm{We}$ therefore determined the in vitro stability of the parent peptide, KSL-128018, KSL-128114 and peptides 1-4 in human plasma. The phage display derived parent peptide showed a half-life of $8.5 \mathrm{~min}$ in human plasma, whereas the optimized peptide KSL-128018 had a >170 fold improved stability, with a $\mathrm{T}_{1 / 2}>24 \mathrm{~h}$ (Figure $2 \mathrm{~F}$ ). In addition, the CPP-tagged peptides comprising only L-amino acids in the CPP sequence, showed a half-life of 1-2 h. By incorporating both Land D-amino acids, as in peptides $\mathbf{1}$ and $\mathbf{2}$, the half-life increased to $>24 \mathrm{~h}$, and during the $24 \mathrm{~h}$ timeframe used for the assay, we could not detect differences in stability between the cyclic TAT containing peptide (1) and the linear counterpart (2), as both peptides were extremely stable. Another potential route for peptide drug elimination is through hepatic clearance, thus we analyzed the stability of the same peptides in mouse hepatic microsomes. All seven peptides, the parent peptide, KSL-128018, KSL-128114 and 1-4, had $\mathrm{T}_{1 / 2}$ $>60$ min, compared to the control (propanol) with a half-life of $35 \mathrm{~min}$ (Figure $2 \mathrm{G}$ ), thus indicating that hepatic clearance is not likely to be an issue for the peptides described here.

In vivo activity of inhibitor. Syntenin is known to influence cancer progression ${ }^{5}$ and regulate exosomal biogenesis by supporting the formation of intracellular vesicles inside 
multivesicular bodies in a PDZ-dependent manner. ${ }^{9-10,15}$ As a measure of the effects of our peptide inhibitors on the syntenin-mediated exosomal pathway, we first investigated the ability of the peptides to inhibit the intracellular endosomal budding of syntenin. This method validates target engagement at a cellular level and also provides a measure of the cell permeability properties of these peptides, as they have to permeate the cell membrane to inhibit this interaction. $^{26}$ MCF-7 cells overexpressing mCherry-labelled syntenin and Rab5 Q79L, a constitutively active Rab5 that develops enlarged cytoplasmic vesicles in which endosomal budding takes place, was subjected to increasing concentrations of the five cell penetrating peptides, KSL-128114 and 1-4, over 24 h. Peptides KSL-128114 and 1-4 all showed an inhibitory effect on the fluorescent signal from syntenin and thus on endosomal budding, with peptides KSL-128114, 1 and 3-4 showing a dose dependent inhibition (0.1, 5 and 10 $\mu \mathrm{M}$, Figure 4E and Figure S4). This concentration range for CPP-containing peptides is comparable with previously reported concentrations $(5-150 \mu \mathrm{M})$ required to permeate cancer cells. ${ }^{27-28}$ Thus, peptides KSL-128114 and 1-4 permeate MCF-7 cells and inhibit syntenin dependent endosomal budding.

Next, we examined the anti-neoplastic effect of peptides KSL-128114 and 1-2. Highly invasive human melanoma cell line (A2058), colorectal adenocarcinoma (HT29) and breast adenocarcinoma (MCF-7) cells were treated with increasing concentrations of peptides KSL-128018, KSL-128114 or 1-2 for $72 \mathrm{~h}$. Treatment with all three peptides carrying a CPP moiety, KSL-128114 or 1-2, but not peptide KSL-128018, resulted in a decreased cell viability of human melanoma cells in a dose dependent manner and had no or limited effect on the colon or breast cancer cells (Figure 4A and Figure S5). In particular, peptide KSL-128114 inhibited all melanoma cells at a concentration of $20 \mu \mathrm{M}$. KSL-128018 showed no inhibitory effect, suggesting that this peptide do not permeate cell membranes and underlines the importance of the CPP motifs. Peptide KSL-128114 was further assessed using two patient-derived GBM cell cultures, GBM001 and GBM002. Gratifyingly, GBM cell viability was significantly reduced after treatment with KSL-128114 in a dose dependent manner (Figure 4B and Figure S5). Altogether, these results substantiate the key importance of syntenin in melanoma and glioblastoma pathogenesis. In addition, we addressed the cell-permeability and distribution of TAMRAconjugated KSL-128114 in the cytosol of GBM002 cells (Figure S6); we observed a clear time and concentration dependent uniform distribution of KSL-128114 in the cytoplasm of the cells.

Encouraged by the in vitro profile of peptide KSL-128114, we examined if KSL-128114 could uncouple native syntenin dependent PPIs in vivo and hence inhibit the progression of GBM. First, patient-derived GBM cells, previously shown to form infiltrative malignant tumours in mice, ${ }^{29}$ were pretreated with KSL-128114, before stereotactically implanted into the right frontal lobes of mice. Animals were monitored daily for neurological impairment and weight loss, to which point they were sacrificed. Gratifyingly, animals receiving peptide KSL-128114 showed a remarkable and significant prolonged survival (median survival $=45.5$ days), compared to animals treated with the control peptide KSL-128018 (median survival $=34$ days) $($ Figure $4 \mathrm{H}, \mathrm{I}),{ }^{29}$ or DMSO
$($ median survival $=$ ca 25 days $) .{ }^{29}$ This confirms the important function of the CPP tag and demonstrates the applicability of peptide KSL-128114 as a novel tool compound for deciphering the role of syntenin in GBM progression.

\section{DISCUSSION AND CONCLUSIONS}

The critical role of syntenin in cancer pathogenesis has become increasingly evident. Therefore, syntenin is considered as a potential, novel therapeutic target for inhibition of cancer cell invasion and metastatic spread. In particular, increased expression of syntenin has a direct clinical correlation with shorter survival in patients with glioblastoma, breast cancer and uveal melanoma..$^{5,730-31}$ Despite the intriguing role of syntenin in cancer, only two low affinity inhibitors have been described. ${ }^{32-33}$ In general, developing inhibitors for PDZ domain proteins have proven to be a challenge, and so far only a limited number of small molecule PDZ domain inhibitors have been developed for putative drug targets, such as PSD-95, dishevelled, protein interacting with C $\alpha$-kinase 1 (PICK1) and very recently also for syntenin. ${ }^{33-35}$ However, these small molecules generally suffer from low affinity to the PDZ domain protein, which hamper them as attractive drug leads. In contrast, peptide-based PDZ inhibitors have shown great promise, exemplified by the 20-mer PSD-95 peptide inhibitor, NA- $1,{ }^{36}$ which is currently undergoing phase III clinical studies for the treatment of acute cerebral ischemia brain damage. Similarly, a high affinity dimeric peptide-based PSD-95 inhibitor has shown great promise and is currently enter Phase I clinical studies. ${ }^{37}$

Inspired by the recent progress in the development of peptide-based PDZ domain inhibitors, we exploited a heptameric peptide recently identified by phage display. ${ }^{16}$ This led to the discovery of peptide KSL-128018, with a marked increase in affinity towards syntenin with $K_{\mathrm{d}}$ of $30 \mathrm{nM}$ and a distinct preference for syntenin PDZ1 over 254 human PDZ domains. This peptide is to the best of our knowledge, also the most potent monomeric peptide-based inhibitor of any PDZ domain. PDZ domains are typically classified according to the tetrameric consensus recognition sequences within the C-terminal of their peptide binding partners. ${ }^{20}$ According to the single previously determined X-ray crystal structure of a peptide ligand (TNEFYF) bound to syntenin PDZ1, only the amino acids in position 0 and -1 are located in the binding site. ${ }^{38}$ Interestingly, peptide KSL-128018 shows an unusual affinity dependence based on side chains in position 0 , $1,-2$ and -4 . This indicates that additional interaction sites are formed, spanning outside the canonical binding site. Such a non-canonical binding mode is further supported by introduction of backbone amide-to-ester substitutions in position 0 to -4 of the peptide inhibitor, which result in a 20 to $>300$-fold decrease in affinity. The extended binding mode was confirmed by an X-ray crystal structure of peptide KSL-128018 in complex with syntenin PDZ1. Backbone hydrogen bonds have previously been shown to play a pivotal role in peptide-PDZ interactions. ${ }^{39-40}$ Our observations for peptide KSL-128018 show an intriguing involvement of the backbone amide bonds, compared to both the PDZ1TNEFYF interaction and other reported PDZ-peptide interactions. ${ }^{38-39,41}$

As syntenin is an intracellular target, a successful delivery strategy of peptide KSL-128018 had to be integrated into the peptide design. A number of different drug candidates con- 
jugated to CPPs are currently in clinical trials, exemplified by TAT conjugation in NA-1 ${ }^{36}$ and AM-111, ${ }^{42}$ which has recently passed phase II clinical studies. We investigated the effect of conjugating different CPP sequences in the Nterminal of peptide KSL-128018 on cell permeability, by evaluating the effect on syntenin endosomal budding and cancer cell viability. The number of endosomes undergoing syntenin budding (as a measure of exosome biogenesis) ) $^{9-10,15}$ in breast cancer cells was decreased upon treatment with any of the five CPP conjugated peptides, KSL-128114 and 1-4, in a dose dependent manner. The concentration needed to observe an inhibitory effect of the number of formed exosomes are in line with what has previously been reported for TAT-conjugated cargo into HeLa cells. ${ }^{28}$ Recent efforts have suggested that cyclized TAT can have an improved uptake profile. ${ }^{28} \mathrm{We}$ did not observe that cyclisation of TAT induced a more efficient inhibition of endosomal budding and nor did it have a beneficial effect on cell viability of A2058 melanoma cells. Proteolytic degradation is a general concern for peptide-based drugs ${ }^{43}$ and therefore metabolic stability in both human plasma and mouse hepatic microsomes was evaluated for the CPP-tagged inhibitors and used as a guide to which inhibitors should be pursued further. CPP conjugated peptides comprising a combination of both L- and Damino acids had a greatly improved metabolic stability profile in human plasma and mouse microsomes, whereas no effect of cyclisation of the CPP moiety was observed. Collectively these studies identified compound KSL-128114 as a lead compound with very high affinity to syntenin, high metabolic stability, and efficient ability to inhibit cancer cell viability.

Understanding the benefits and limitations of GBM in vivo and ex vivo models is crucial for the preclinical development of efficacious inhibitors. Here, we have utilized patientderived GBM xenograft models, which is arguably superior to cell line derived GBM models. Commonly, cell line-based models grown in serum containing media show poor genotypic and phenotypic resemblance to their parent tumours. ${ }^{44}$ Recently, a small molecule inhibitor of syntenin was described to inhibit the progression of GBM in both a patientderived GBM xenograft model as well as in a cancer cell line (U1242) based GBM xenograft model. Here, the overall survival for the control treated mice in the two models differ significantly (19 and 41 days, respectively), ${ }^{33}$ highlighting the importance of using and comparing appropriate GBM models. The small molecule inhibitor, 113B7 was administered i.p. (30 mg/kg) to patient-derived GBM xenograft mice three times per week for two weeks. The mean overall survival of these animals was determined to $<25$ days. ${ }^{33}$ Here, we show that treatment with KSL-128114 has a superior survival profile, compared with $113 \mathrm{~B} 7$ in a similar in vivo model, with a median survival of 45 days. Noteworthy, KSL128114 was only given to patient-derived GBM cells as a single pre-treatment dose $(50 \mu \mathrm{M})$ prior to tumour establishment.

In conclusion, we have designed and synthesized a high affinity monomeric peptide-based inhibitor targeting the scaffold protein syntenin. The inhibitor displays high metabolic stability, cell penetrating properties, inhibits cell proliferation of melanoma and primary GBM cells in a dosedependent manner and significantly extend the survival time in patient-derived GBM-bearing mice. This peptide inhibitor is a novel lead for treatment of glioblastoma and could be- come a valuable pharmacological tool for further deciphering the crucial role of syntenin in cancer progression and the development of metastasis. Future studies should focus on determining the downstream cell signaling pathways effected by inhibition of syntenin and if treatment combined with radiation can prolong the survival even further. Further research will also be required to elucidate if syntenin can be exploited as a drug target for treatment of glioblastoma in patients. Specifically for KSL-128114 studies addressing in vivo blood-brain barrier permeation, as well as in vivo toxicity and studies of pharmacodynamic and pharmacokinetic properties are required.

\section{EXPERIMENTAL PROCEDURES}

Materials and Methods. Preloaded Wang resin, preloaded 2chlorotrityl resin, 2-cholortrityl chloride resin and 9fluorenylmethoxycarbonyl (Fmoc) protected amino acids were purchased from Iris Biotech. 5,6-carboxytetramethylrhodamine (TAMRA) was obtained from Anaspec. Organic solvents were of analytical grade or higher. Preparative and semi-preparative reverse phase high performance liquid chromatography (RPHPLC) was performed on a Waters 2545 system using a C18 column (Agilent Zorbax $300 \mathrm{SB}-\mathrm{C} 18,21.2 \mathrm{~mm} \times 250 \mathrm{~mm}$ or $9.4 \times 250 \mathrm{~mm})$ and a linear binary mobile phase comprising Buffer A $\left(95 \% \mathrm{H}_{2} \mathrm{O}, 5 \%\right.$ acetonitrile, $0.1 \%$ trifluoroacetic acid (TFA)) and Buffer B (95\% acetonitrile, $5 \% \mathrm{H}_{2} \mathrm{O}, 0.1 \%$ TFA) with a flow rate of $20 \mathrm{ml} / \mathrm{min}$ or $5 \mathrm{ml} / \mathrm{min}$, respectively. Analytical RP-HPLC was performed using a C18 column (Waters Acquity UPLC BEH C18 $21 \times 50 \mathrm{~mm}$ ) and a linear binary mobile phase comprising Buffer $\mathrm{A}$ and Buffer $\mathrm{B}$ with a flow rate of $0.45 \mathrm{ml} / \mathrm{min}$. $\alpha$-Hydroxy acids were purified by silica gel chromatography on a CombiFlashFr (Teledyne ISCO) by using a linear binary mobile phase comprising dichloromethane (DCM):methanol (10:1). LC-MS analysis was performed on an Agilent 1200 HPLC system coupled to an Agilent 6410 Triple Quadruple Mass Spectrometer using electron spray ionization (ESI), a C18 column (Agilent Zorbax Eclipse XBD-C18, $4.6 \times$ $50 \mathrm{~mm}$ ) and a linear binary mobile phase comprising $95 \% \mathrm{H}_{2} \mathrm{O}$, $5 \%$ acetonitrile, $0.1 \%$ formic acid (FA) and 95\% acetonitrile, $5 \% \mathrm{H}_{2} \mathrm{O}, 0.1 \%$ TFA. All peptides were $\geq 95 \%$ pure as determined by UPLC and LC-MS.

Peptide synthesis. The peptides were synthesised using Fmocbased solid phase peptide synthesis (SPPS) using either manual or automated (Liberty Blue, CEM) synthesis. Fmoc-protected amino acids (4 eq. in relation to functional groups on resin) were dissolved in 4 eq. 2-(1H-benzotriazol-1-yl)-1,1,3,3tetramethyluronium hexafluorophosphate (HBTU) or 4 eq. 2(1H-7-azabenzotriazol-1-yl)-1,1,3,3-tetramethyluronoium hexafluorphosphate (HATU) and 8 eq. diisopropylethylamine (DIPEA) in dimethylformamide (DMF) and added to the resin. The reaction was monitored by the ninhydrin test and allowed to proceed, or recoupled, until desired coupling efficiency was obtained. Fmoc-deprotection was carried out by treating the resin with $20 \%$ piperidine in DMF for $2 \times 2$ min followed by flow wash with DMF. The N-termini of compounds KSL$128018, \mathrm{KSL}-128114$ and 1-4 were acetylated by treating the free N-terminal with 50 eq. acetic anhydride, 30 eq. DIPEA in DMF for $2 \times 5$ min followed by flow wash with DMF. The peptide was obtained by treating the resin with TFA $/ \mathrm{H}_{2} \mathrm{O} /$ triisopropylsilane (TIPS) $(95: 2.5: 2.5)$ for $2 \mathrm{~h}$, followed by filtration, TFA evaporation and precipitation using ice-cold diethyl ether. The peptide was centrifuged and lyophilised to obtain the crude peptide as TFA salt. 
Synthesis of cyclic TAT-peptide. Glu(allyl) and Lys(alloc) were introduced at position -8 and -18 , respectively, in peptide 1 to exploit orthogonal side chain cyclisation on resin. The allyl and alloc protection groups were removed by treating the resin with 20 eq. $\mathrm{PhSiH}_{3}, 0.2$ eq. $\mathrm{Pd}\left(\mathrm{PPh}_{3}\right)_{4}$ in $\mathrm{DCM}$ under $\mathrm{N}_{2}$ for $2 \times$ 15 min followed by extensive flow wash with DCM. The resin was treated with 2 eq. HATU, 2 eq. DIPEA in DMF for $2 \mathrm{~h}$. The deprotection and side chain cyclisation were verified by ninhydrin test and LC-MS (Table S3).

Peptide purification and characterisation. The peptides were purified using a preparative or semi-preparative RP-HPLC system. The molecular weight and the purity of the peptides were confirmed by LC-MS and UPLC (214 nm) (Tables S3). For cell-based assays and in vivo experiment, the peptides were prepared as $\mathrm{HCl}$ salts by dissolving the peptide in $50 \mathrm{mM} \mathrm{HCl}$ followed by lyophilisation. This procedure was repeated three times, to finally obtain the peptides as a $\mathrm{HCl}$ salt.

Synthesis of $\boldsymbol{\alpha}$-hydroxy acids. Six depsipeptides were synthesised by replacing individual $\alpha$-amino acids with the corresponding $\alpha$-hydroxy acids, respectively. Trp(Hoc), Ile and $\operatorname{Asp}(\mathrm{cHx})$ were converted into $\alpha$-hydroxy acids by dissolving 1 eq. of the $\alpha$-amino acid in a mixture of dioxane/ $\mathrm{H}_{2} \mathrm{O} / \mathrm{TFA}$ $(1: 1: 0.1)$ under nitrogen. The reaction was allowed to cool to $0^{\circ} \mathrm{C}$ before addition of 2 eq. of tert-butylnitrite. After $24 \mathrm{~h}$ the solvent was removed in vacuo and the residue was purified by gel filtration chromatography to afford the $\alpha$-hydroxy acid.

(S)-3-(1-((Cyclohexyloxy)carbonyl)-1H-indol-3-yl)-2-

hydroxypropanoic acid (HO-Trp(Hoc)-OH) was obtained as white solid (820 mg, 58\%). ${ }^{1} \mathrm{H}$ NMR (400 MHz, CDCl3) $\delta 8.17$ (t, $J=10.0 \mathrm{~Hz}, 1 \mathrm{H}), 7.62-7.56(\mathrm{~m}, 2 \mathrm{H}), 7.40-7.27(\mathrm{~m}, 2 \mathrm{H})$, $5.03(\mathrm{tt}, J=8.7,3.8 \mathrm{~Hz}, 1 \mathrm{H}), 4.59(\mathrm{dd}, J=7.2,4.0 \mathrm{~Hz}, 1 \mathrm{H}), 3.36$ $-3.07(\mathrm{~m}, 2 \mathrm{H}), 1.84-1.30(\mathrm{~m}, 10 \mathrm{H}) .{ }^{13} \mathrm{C}$ NMR $(100 \mathrm{MHz}$, $\mathrm{CDCl} 3) \delta 177.2,135.6,130.6,125.2,124.9,124.5,122.9,119.3$, $115.5,70.1,63.2,31.8,30.0,25.4,23.8$.

(2S,3R)-2-Hydroxy-3-methylpentanoic acid (HO-Ile-OH) was obtained as white solid (660 mg, 50\%). ${ }^{1} \mathrm{H}$ NMR (400 MHz, $\mathrm{CDCl} 3) \delta 4.18(\mathrm{~d}, J=3.7 \mathrm{~Hz}, 1 \mathrm{H}), 1.96-1.83(\mathrm{~m}, 1 \mathrm{H}), 1.50$ $1.23(\mathrm{~m}, 2 \mathrm{H}), 1.03$ (d, $J=6.9 \mathrm{~Hz}, 3 \mathrm{H}), 0.93$ (t, $J=7.4 \mathrm{~Hz}, 3 \mathrm{H})$. ${ }^{13} \mathrm{C}$ NMR $(100 \mathrm{MHz}, \mathrm{CDCl} 3) \delta 179.6,74.8,39.1,23.8,15.5$, 11.9.

(S)-4-(Cyclohexyloxy)-2-hydroxy-4-oxobutanoic acid (HO-Asp$\mathrm{OH})$ was obtained as yellowish oil $(822 \mathrm{mg}, 38 \%) .{ }^{1} \mathrm{H}$ NMR $\left(400 \mathrm{MHz}, \mathrm{CDCl}_{3}\right) \delta 4.88-4.77(\mathrm{~m}, 1 \mathrm{H}), 4.54(\mathrm{dd}, J=6.1,4.8$ $\mathrm{Hz}, 1 \mathrm{H}), 2.95-2.80(\mathrm{~m}, 2 \mathrm{H}), 1.90-1.67(\mathrm{~m}, 4 \mathrm{H}), 1.57-1.24(\mathrm{~m}$, $6 \mathrm{H}) .{ }^{13} \mathrm{C}$ NMR $\left(100 \mathrm{MHz}, \mathrm{CDCl}_{3}\right) \delta 176.4,171.0,74.4,67.2$, 38.6, 31.6, 25.4, 23.8 .

The conversion of His was performed by treating $3 \mathrm{mmol}$ BocHis(Bom) with $9 \mathrm{ml}$ TFA for $20 \mathrm{~min}$ followed by evaporation. The $\alpha$-hydroxy histidine was isolated by addition of $30 \mathrm{ml}$ water, followed by lyophilisation and RP-HPLC purification. (S)-3-(1-((Benzyloxy)methyl)-1H-imidazol-5-yl)-2-

hydroxypropanoic acid (HO-His(Bom)-OH) was obtained as white solid (414 mg, 50\%). ${ }^{1} \mathrm{H}$ NMR (400 MHz, MeOD) $\delta 8.97$ $(\mathrm{t}, \mathrm{J}=2.0 \mathrm{~Hz}, 1 \mathrm{H}), 7.41-7.28(\mathrm{~m}, 6 \mathrm{H}), 5.83-5.71(\mathrm{~m}, 2 \mathrm{H}), 4.67$ $(\mathrm{d}, \mathrm{J}=1.8 \mathrm{~Hz}, 2 \mathrm{H}), 4.54-4.47(\mathrm{~m}, 1 \mathrm{H}), 3.36(\mathrm{dd}, \mathrm{J}=4.3,1.0 \mathrm{~Hz}$, 1H), 3.23-3.14 (m, 1H). ${ }^{13} \mathrm{C}$ NMR (100 MHz, MeOD) $\delta 175.8$, 137.6, 136.9, 132.9, 129.7, 129.4, 129.0, 78.0, 73.1, 70.2.

The $\alpha$-hydroxy acids of Tle and Chg were commercially available.

Synthesis of depsipeptides. Depsipeptide Ile0 0 was manually synthesised by Fmoc-based SPPS strategy by swelling $0.1 \mathrm{mmol}$ 2-chlorotrityl chloride resin in dry DCM for $1 \mathrm{~h}$, followed by addition of 4 eq. $(2 S, 3 R)$-2-hydroxy-3-methylpentanoic acid and
8 eq. DIPEA in dry DCM. The reaction was allowed to proceed for $1 \mathrm{~h}$ at room temperature and the resin was subsequently washed with DCM and DMF. The reaction was repeated twice. The ester bond formation was achieved by dissolving 5.5 eq. of Fmoc-Asp(tBu) in $1 \mathrm{ml}$ DCM/DMF $(1: 1)$ and 5 eq. $N, N^{\prime}-$ diisopropylcarbodiimide (DIC), which was cooled on ice for 15 min before the mixture was added to the resin together with 0.1 eq. 4-dimethylaminopyridine (DMAP) and 2 eq. $N$-ethylmorpholine (NEM). The reaction was agitated for $1 \mathrm{~h}$ at room temperature after which the resin was washed with DCM and DMF. The coupling step was repeated twice. Subsequent Fmoc deprotection, coupling steps and cleavage from the resin were carried out as described above.

Depsipeptides Chg-2 $\phi$ and Tle-3ळ were synthesised on 0.1 mmol preloaded Fmoc-Ile-Wang resin by Fmoc-based SPPS. The resin was swelled in DMF for $1 \mathrm{~h}$ followed by Fmocprotection, as described above. Coupling of 5.5 eq. $\alpha$-hydroxy acid was carried out by premixing the $\alpha$-hydroxy acid in $1 \mathrm{ml}$ ice cold DCM/DMF (1:1), 5 eq. DIC and 6 eq. hydroxybenzotriazole (HOBt) for $15 \mathrm{~min}$ before addition to the resin together with 2 eq. NEM. The reaction was allowed to agitate for $20 \mathrm{~min}$ at room temperature and the resin was subsequently washed with DCM and DMF. The coupling was repeated twice. The ester bond formation and subsequent Fmoc-deprotection, coupling steps and cleavage from the resin were carried out as described above.

Depsipeptides Asp- $1 \delta$, Trp-4 $\omega$ and His- $5 \eta$ were manually synthesised by Boc-based SPPS on $0.1 \mathrm{mmol}$ preloaded Boc-IlePAM resin. In general, the resin was swelled in dry DCM for 1 $\mathrm{h}$ and Boc deprotection was carried out by neat TFA for $2 \times 1$ min followed by washes with DCM and DMF. Coupling of 4 eq. $\alpha$-amino acids were carried out in 4 eq. HBTU, 8 eq. DIPEA in dry DMF for $30 \mathrm{~min}$. For coupling of the $\alpha$-hydroxy acid in

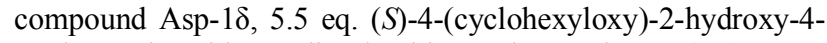
oxobutanoic acid was dissolved in $9 \mathrm{ml}$ DCM/DMF (1:1), 5 eq. DIC and 6 eq. HOBt on ice. After 15 min the mixture was added to the resin together with 2 eq. NEM followed by agitation for $20 \mathrm{~min}$ at room temperature. The resin was drained and washed with DCM and DMF. Ester bond formation was achieved by dissolving 5.5 eq. of the subsequent Boc-protected amino acid in $1 \mathrm{ml} \mathrm{DCM} / \mathrm{DMF}$ (1:1) and 5 eq. DIC on ice for $15 \mathrm{~min}$ before the mixture was added to the resin together with 0.1 eq. DMAP, 2 eq. NEM and agitation was allowed for $1 \mathrm{~h}$ at room temperature. The resin was washed with DCM and DMF and the coupling was repeated twice. The final cleavage of the peptide was achieved by treating the resin with anhydrous hydrogen fluoride (HF)/p-cresol/resorcinol $(9: 0.5: 0.5)$ for $1 \mathrm{~h}$ at $0^{\circ} \mathrm{C}$ on a $\mathrm{HF}$ reaction apparatus (Peptides International). The crude peptide was precipitated with ice-cold diethyl ether and centrifuged at $3500 \mathrm{rpm}$ at $4^{\circ} \mathrm{C}$ for $15 \mathrm{~min}$. The supernatant was discarded and the pellet was dissolved in Buffer A/B (50:50) followed by lyophilizing and RP-HPLC purification.

The synthesis of depsipeptide Trp- $4 \omega$ was performed as above with minor modifications. The coupling of the $\alpha$-hydroxy acid was achieved by dissolving 5.5 eq. (S)-3-(1((cyclohexyloxy)carbonyl)-1H-indol-3-yl)-2-hydroxypropanoic acid in 5 eq. DIC, 6 eq. HOBt and 2 eq. NEM for $15 \mathrm{~min}$ and the ester bond was formed by repeating the coupling of the subsequent Boc protected amino acid four times followed by deprotection of Boc $(6 \times 1 \mathrm{~min})$.

Depsipeptide His- $5 \eta$ was synthesized as above except the coupling of (S)-3-(1-((benzyloxy)methyl)-1H-imidazol-5-yl)-2hydroxypropanoic acid was achieved by addition of 3.8 eq. DIPEA, 4. eq HOBt and 4 eq. DIPEA for $1 \mathrm{~h}$. The ester bond was formed by repeating the coupling of the subsequent $\alpha$ - 
amino acid four times. All six depsipeptides were characterised using LC-MS and UPLC (Table S3).

Protein expression. Syntenin PDZ1-2 was cloned into a pETM11 vector, expressed in BL21 (BE3) polyLysS cells and purified using HisTrap FF column. Syntenin PDZ1 was cloned in a pET$21 \mathrm{~b}$ vector, expressed in BL21 (DE3) cells and purified using Ni-NTA Superflow column.

Fluorescence polarisation assay. To determine the dissociation constant $\left(K_{\mathrm{d}}\right)$ of the fluorescent probes (TAMRA-NNGSHWTIDI and TAMRA-NNG-SHW(Tle)(Chg)DI), solutions of increasing concentrations of syntenin PDZ1-2 in $25 \mathrm{mM}$ HEPES, $0.15 \mathrm{M} \mathrm{NaCl}, 1 \mathrm{mM} \beta$-mercaptoethanol, pH 7.4 were prepared. The protein solutions were diluted with $200 \mathrm{nM}$ TAMRA-NNG-SHWTIDI or TAMRA NNGSHW(Tle)(Chg)DI , in black flat bottom low-binding 384-well plates (Corning), to generate a final fluorescent probe concentration of $100 \mathrm{nM}$. The samples were incubated for $5 \mathrm{~min}$ at room temperature. The fluorescent polarisation was read on a Tecan Safire $^{2}$ platereader at excitation/emission of $530 / 585 \mathrm{~nm}$. The data was fitted to a non-linear one-site saturation binding curve in Prism 6 to determine the $K_{\mathrm{d}}$ value. To resolve the affinities for the unlabelled peptides, $100 \mathrm{nM}$ syntenin PDZ12, $100 \mathrm{nM}$ TAMRA-NNG-SHWTIDI or TAMRA-NNGSHW(Tle)(Chg)DI and increasing concentrations of cold peptide was prepared in black flat bottom low-binding 384-well plates. The fluorescent polarisation was determined as describe for the saturation binding experiments. Data was fitted to a sigmoidal dose-response curve in Prism 6 by using the equation $\mathrm{Y}=$ Bottom $+($ Top-Bottom $) /\left(1+10^{(\log I C 50-\mathrm{X}) \text {-Hill Slope }}\right)$, where $\mathrm{X}$ is the cold ligand concentration in $\log$ units. The generated $\mathrm{IC}_{50}$ values was converted to $K_{\mathrm{i}}$ values, as previously described (30).

Surface plasmon resonance (SPR). KSL-128018 was biotin labelled on the N-terminal and immobilised on a streptavidin sensor chip. Increasing concentrations of syntenin-1 PDZ1-2 and syntenin-2 PDZ1-2 were freshly prepared and analysed on a BIAcore T200. Sensorgrams were collected and the $K_{\mathrm{d}}$ values were determined based on the ratio of the association and dissociation rate constants, as previously described ${ }^{45}$.

High-throughput screening of the human PDZome. To determine the PDZ binding profile of peptide KSL-128018, 255 single human PDZ domains were expressed and screened against the N-terminal biotinylated peptide KSL-128018, as previously described ${ }^{46}$.

Crystallization and structure determination. PDZ1 domain was concentrated to $15 \mathrm{mg} / \mathrm{ml}$ in $20 \mathrm{mM}$ Tris- $\mathrm{HCl}$, pH 7.5, 150 $\mathrm{mM} \mathrm{NaCl}, 3 \mathrm{mM}$ DTT, and $0.01 \% \mathrm{NaN}_{3}$. Then, it was mixed with peptide KSL-128018 at a 1:1 molar ratio and complex crystals were grown at $16{ }^{\circ} \mathrm{C}$ in a $1.5 \mu \mathrm{l}$ micro batch under oil containing equal volumes of protein solution and mother liquor $(0.2 \mathrm{M}$ ammonium sulfate, $0.1 \mathrm{M}$ sodium acetate trihydrate, $\mathrm{pH}$ $4.6,30 \%$ polyethylene glycol monomethyl ether 2,000]. Crystals were cryo-protected in reservoir solution supplemented with $17 \%$ (v/v) ethylene glycol. Diffraction data for the syntenin PDZ1 and peptide inhibitor complex were collected at $1.8 \AA$ resolution, respectively, at beam line $5 \mathrm{C}$ at Pohang Accelerator Laboratory (PAL), Korea. Data were processed and scaled using HKL2000 ${ }^{47}$. The space groups of syntenin PDZ1/KSL-128018 complex was determined as C121 ( $a=95.58 \AA, b=38.396 \AA, c=$ 56.777, $\alpha=\gamma=90^{\circ}, \beta=92.523^{\circ}$ ) and structures were solved using the molecular replacement method with the program PHENIX ${ }^{48}$. The crystallographic model was built using the COOT ${ }^{48}$ program and refined in PHENIX ${ }^{49}$. The statistics for structure refinement are summarized in Table S7. The coordinates of syntenin PDZ1/KSL-128018 complex has been deposited to the protein data bank with the accession code 5 YA7.

Pull-down of syntenin from brain lysate. Mouse brain lysate was prepared from adult C57BL/6 animals. Brains were removed after cervical dislocation and rapidly homogenized in 20 mM HEPES, $100 \mathrm{mM} \mathrm{KCH}_{3} \mathrm{COOH}, 40 \mathrm{mM} \mathrm{KCl}, 5 \mathrm{mM}$ EGTA, $5 \mathrm{mM} \mathrm{MgCl}_{2}, 5 \mathrm{mM}$ DTT, $1 \mathrm{mM}$ PMSF, $1 \%$ Triton $\mathrm{X}$ and protease inhibitor Roche complete, $\mathrm{pH} 7.2$, using a piston homogenizer and centrifuged at $10.000 \times \mathrm{g}$ for $15 \mathrm{~min}$. The supernatant was flash-frozen in liquid nitrogen and stored at $-80^{\circ} \mathrm{C}$ until further use. Analogues of peptides KSL-128018 and the non-binding scrambled peptide bearing an additional N-terminal cysteine reactive group for immobilization, were loaded on magnetic Dynabeads M-270 epoxy resin beads. (Life Technologies). The resin slurry was prepared according to manufacturer's protocol. The peptides were dissolved in 10\% DMSO, $2 \mathrm{M}$ ammonium sulfate in PBS, $10 \mathrm{mM}$ TCEP, $\mathrm{pH} 7.6$ and incubated with the resin for $48 \mathrm{~h}$ at $37^{\circ} \mathrm{C}$. The peptide coated resin was incubated with brain lysate for $15 \mathrm{~min}$ at $37^{\circ} \mathrm{C}$. Isolated proteins were eluted by boiling the beads in Laemmli buffer containing $10 \mathrm{mM}$ TCEP. The eluate was analysed by SDS-PAGE followed by Western blot against syntenin by using the primary antibody $\mathrm{C} 3$ at a dilution of 1:1000 (Santa Cruz Biotechnologies).

In vitro plasma stability. Human plasma was preheated at $37^{\circ} \mathrm{C}$ for $15 \mathrm{~min}$ before spiked with a final concentration of $0.2 \mathrm{mM}$ parent peptide, KSL-128018 and the six cell-penetrating analogs. Samples were collected after 0, 1, 2, 4, 6 and 24 h or after $0,2,5,10,30$ and $60 \mathrm{~min}$, depending on stability. The compounds were extracted from the plasma by either pre-treatment with $6 \mathrm{M}$ urea for $10 \mathrm{~min}$ followed by addition of $20 \%$ trichloroacetic acid (TCA) or pre-treatment with $26 \mathrm{mg}$ guanidine hydrochloride $(\mathrm{GuHCl})$ followed by addition of $10 \%$ TCA in acetone. The samples were centrifuged at $13400 \mathrm{rpm}$ for $10 \mathrm{~min}$ and the supernatant was analysed by UPLC $(214 \mathrm{~nm})$. The area under the curve (AUC) was determined and normalized to time point 0 $\mathrm{h}$. The half-life $\left(\mathrm{T}_{1 / 2}\right)$ was determined by fitting the data to a one-phase decay equation in Prism 6. The data is represented as the mean of three individual experiments \pm SEM.

In vitro hepatic clearance. Peptides were incubated in mouse hepatic microsomes supplemented with $1 \mathrm{mM}$ NADPH and 3 $\mathrm{mM} \mathrm{MgCl}$ for up to $60 \mathrm{~min}$. The peptides were extracted from the microsomes and analysed by UPLC. and $5 \mathrm{mM}$ parent peptide, KSL- 128018 and the six cell-penetrating analogs at $37^{\circ} \mathrm{C}$ for $0,5,10,15,30,45$ and $60 \mathrm{~min}$. The peptides were extracted by pre-treatment with $6 \mathrm{M}$ urea for $15 \mathrm{~min}$ followed by addition of $100 \mu \mathrm{l}$ acetonitrile or by pre-treatment with $6 \mathrm{M} \mathrm{GuHCl}$ for $15 \mathrm{~min}$ followed by addition of $100 \mu 10 \%$ TCA in acetone. The samples were centrifuged at $13400 \mathrm{rpm}$ form $15 \mathrm{~min}$ before analysed by UPLC $(214 \mathrm{~nm})$. The AUC was determined and normalized to time point $0 \mathrm{~min}$. The data was fitted to a onephase decay equation to determine the $\mathrm{T}_{1 / 2}$. The data is presented as mean of three individual experiments \pm SEM.

Cancer cell viability. The effect of peptides KSL-128018 and KSL-128114 was tested on a highly invasive human melanoma, A2058 (ATCC: CRL-11147), colorectal adenocarcinoma, HT29 (ATCC: HTB-38) and breast adenocarcinoma, MCF-7 (ATCC: HTB-22), cell lines as previously described ${ }^{50}$. The inhibitory effect of peptides KSL-128018 and KSL-128114 was further evaluated using two primary GBM cells, GBM001 and GBM002. The glioblastoma cells were maintained through subcutaneous xenografting in the flanks of BALB/c $(\mathrm{nu} / \mathrm{nu})$ mice. Tumors were dissected out and dissociated using papain 
dissociation system (Worthington Biochemical). Acutely (max culture time $24 \mathrm{~h}$ post dissection from mice) dissociated cells were cultured in Neurobasal A media supplemented with B27 supplement minus vitamin A (Invitrogen), epidermal growth factor and basic fibroblast growth factor $(10 \mathrm{ng} / \mathrm{ml}$, Invitrogen). Cells were cultured at $37{ }^{\circ} \mathrm{C}$ in an atmosphere of $5 \% \mathrm{CO}_{2}$. Acutely dissociated single cells were plated into a 96-well plate at 3000 cells/well in triplicates. Next day, vehicle or peptide inhibitor was added and cell viability was measured after $72 \mathrm{~h}$ using CellTiter-Glo Luminescent Cell Viability Assay (Promega). Results were calculated as relative fold change in ATP with each group internally normalized to the respective vehicle control. The experiments were performed three times in triplicate and the data is presented as mean $\pm \mathrm{SD}$.

Inhibition of microsomal budding. The inhibition of syntenindependent intraluminal vesicle (ILV) budding was determined as previously described ${ }^{51}$. Briefly, MCF-7 cells (ATCC: HTB22) were grown in DMEM/F12 (1:1) medium supplemented with $10 \%$ fetal calf serum. The cells were transfected the day after plating with mCherry-syntenin and Ce-RAB5(Q79L) using Fugene HD (Roche). Cells were treated for $24 \mathrm{~h}$ with vehicle $(0.1 \%$ DMSO in sterilised water) or with increasing concentrations of KSL-128018, KSL-128114 or 1-4. The number of mCherry-syntenin filled Ce-RAB5(Q79L) endosomes were analysed with confocal microscopy. The data is presented as the mean of two individual experiments, where at least 40 endosomes were examined in each experiment.

\section{Peptide cytoplasmic distribution}

Patient-derived GBM002 cells were grown on Geltrex-coated (A1413202-Thermo Fisher Scientific) coverslips and treated with vehicle (DMSO) or increasing concentrations of KSL128114-TAMRA. After 2 and 24 hours of treatment, cells were fixed with 4\% PFA (Paraformaldehyde) in PBS 1x and the nuclei were stained with 4,6-diamino-2-phenylindole (DAPI, D9542-Sigma Aldrich). The acquisition and analysis of the images were performed using Zeiss LSM 800 Confocal microscope.

In vivo xenograft GBM mouse model. Patient-derived GBM cells were pre-incubated with $50 \mu \mathrm{M}$ KSL-128018 or KSL128114 for $24 \mathrm{~h}$ to allow for uptake. $24 \mathrm{~h}$ later 10,000 viable cells (trypan blue method was employed to exclude dead cells prior counting, using Countess automated cell counter, Life Technologies) were stereotactically implanted into the right frontal lobes of NMRInu-F mice (female, 8 weeks). Mice were monitored daily for neurological impairment and weight loss, at which point they were sacrificed. GBM animal study described were approved by the Danish Regulations for Animal Welfare (Protocol Number 2012-15-2934-00636).

\section{ASSOCIATED CONTENT}

\section{Supporting Information}

The Supporting Information is available free of charge on the ACS Publications website.

\section{Accession Codes}

PDB code for PDZ1 domain with bound KSL-128018 is 6AK2.

\section{AUTHOR INFORMATION}

\section{Corresponding Authors}

*Correspondence should be addressed to Linda HaugaardKedström, Department of Drug Design and Pharmacology, University of Copenhagen, (1.haugaardkedstrom@sund.ku.dk), Weontae Lee, Department of Biochemistry, College of Life Science and Biotechnology, Yonsei University (wtlee@yonsei.ac.kr) or to Kristian Strømgaard, Department of Drug Design and Pharmacology, University of Copenhagen, (kristian.stromgaard@sund.ku.dk)

\section{Authors Contributions}

$\dagger$ L. S. C., V.S. and Z. J. contributed equally.

\section{Present Addresses}

$\ddagger$ (L.M.H.K.) Present address: Polypeptide Group, Limhamnsvägen 108, 20061 Limhamn, Sweden.

\section{Funding Sources}

This work was supported by the Lundbeck foundation (K.S), the Swedish Research Council (LMHK) and the National Research Foundation of Korea (WL, NRF-2017R1A2B2008483). The work in PZ laboratory was supported by the National Research Agency (ANR, Investissements d'Avenir, A*MIDEX project ANR-11-IDEX-0001-02), the Fund for Scientific ResearchFlanders (G.08646.15N) and the foundation ARC pour la Recherche sur le Cancer (PJA 20161204584). Raphael Leblanc is the recipient of postdoctoral fellowship of the Foundation ARC pour la Recherche sur le Cancer (PDF20151203700) and Antonio Luis Egea-Jimenez of la Ligue contre le Cancer (France).

\section{Notes}

The University of Copenhagen has filed a patent application on peptide inhibitors described herein with L.M.H.K., L.C.S. and K.S. as inventors.

\section{ACKNOWLEDGMENTS}

Søren W. Pedersen and Ida A. Nilsson are acknowledged for experimental input and reference editing, respectively.

\section{ABBREVIATIONS}

GBM, glioblastoma; Chg, cyclohexyl glycine; FP, fluorescence polarization; FAK, focal adhesion kinase; GBM, glioblastoma; MAPK, p38 mitogen-activated protein kinase; Mda-9, melanoma differentiation associated gene-9; MMP, matrix metalloproteinase; NF- $\kappa \mathrm{B}$, nuclear factor-kappa B; PDZ, postsynaptic density protein-95/discs-large/zona occludens-1; PICK1, protein interacting with $\mathrm{C} \alpha$-kinase 1; PSD-95, postsynaptic density protein-95; PPI, Protein-protein interactions; SPR, surface plasmon resonance; Tle, tert-butyl glycine.

\section{REFERENCES}

(1) Dev, K. K., Making protein interactions druggable: targeting PDZ domains. Nat. Rev. Drug Discovery 2004, 3, 1047-1056.

(2) Luck, K.; Charbonnier, S.; Trave, G., The emerging contribution of sequence context to the specificity of protein interactions mediated by PDZ domains. FEBS Lett. 2012, 586, 2648-2661.

(3) Koroll, M.; Rathjen, F. G.; Volkmer, H., The neural cell recognition molecule neurofascin interacts with syntenin-1 but not with syntenin-2, both of which reveal self-associating activity. J. Biol. Chem. 2001, 276, 10646-10654.

(4) Lin, J. J.; Jiang, H. P.; Fisher, P. B., Characterization of a novel melanoma differentiation-associated gene, mda-9, that is 
down-regulated during terminal cell differentiation. Mol. Cell Differ. 1996, 4, 317-333.

(5) Kegelman, T. P.; Das, S. K.; Emdad, L.; Hu, B.; Menezes, M. E.; Bhoopathi, P.; Wang, X. Y.; Pellecchia, M.; Sarkar, D.; Fisher, P. B., Targeting tumor invasion: the roles of MDA9/Syntenin. Expert Opin. Ther. Targets 2015, 19, 97-112.

(6) Overall, C. M.; Lopez-Otin, C., Strategies for MMP inhibition in cancer: innovations for the post-trial era. Nat. Rev. Cancer 2002, 2, 657-672.

(7) Kegelman, T. P.; Das, S. K.; Hu, B.; Bacolod, M. D.; Fuller, C. E.; Menezes, M. E.; Emdad, L.; Dasgupta, S.; Baldwin, A. S.; Bruce, J. N.; Dent, P.; Pellecchia, M.; Sarkar, D.; Fisher, P. B., MDA-9/syntenin is a key regulator of glioma pathogenesis. Neuro-oncology 2014, 16, 50-61.

(8) Boukerche, H.; Aissaoui, H.; Prevost, C.; Hirbec, H.; Das, S. K.; Su, Z. Z.; Sarkar, D.; Fisher, P. B., Src kinase activation is mandatory for MDA-9/syntenin-mediated activation of nuclear factor-kB Oncogene 2010, 29, 3054-3066.

(9) Baietti, M. F.; Zhang, Z.; Mortier, E.; Melchior, A.; Degeest, G.; Geeraerts, A.; Ivarsson, Y.; Depoortere, F.; Coomans, C.; Vermeiren, E.; Zimmermann, P.; David, G., Syndecan-synteninALIX regulates the biogenesis of exosomes. Nat. Cell Biol. 2012, 14, 677-685.

(10) Ghossoub, R.; Lembo, F.; Rubio, A.; Gaillard, C. B.; Bouchet, J.; Vitale, N.; Slavik, J.; Machala, M.; Zimmermann, P., Syntenin-ALIX exosome biogenesis and budding into multivesicular bodies are controlled by ARF6 and PLD2. Nat. Commun. 2014, 5, 3477.

(11) Peinado, H.; Aleckovic, M.; Lavotshkin, S.; Matei, I.; Costa-Silva, B.; Moreno-Bueno, G.; Hergueta-Redondo, M.; Williams, C.; Garcia-Santos, G.; Ghajar, C.; Nitadori-Hoshino, A.; Hoffman, C.; Badal, K.; Garcia, B. A.; Callahan, M. K.; Yuan, J.; Martins, V. R.; Skog, J.; Kaplan, R. N.; Brady, M. S.; Wolchok, J. D.; Chapman, P. B.; Kang, Y.; Bromberg, J.; Lyden, D., Melanoma exosomes educate bone marrow progenitor cells toward a pro-metastatic phenotype through MET. Nat. Med. 2012, 18, 883-891.

(12) Sung, B. H.; Ketova, T.; Hoshino, D.; Zijlstra, A.; Weaver, A. M., Directional cell movement through tissues is controlled by exosome secretion. Nat. Commun. 2015, 6, 7164 .

(13) Steeg, P. S., Targeting metastasis. Nat. Rev. Cancer 2016, 16, 201-218.

(14) Costa-Silva, B.; Aiello, N. M.; Ocean, A. J.; Singh, S.; Zhang, H.; Thakur, B. K.; Becker, A.; Hoshino, A.; Mark, M. T.; Molina, H.; Xiang, J.; Zhang, T.; Theilen, T. M.; GarciaSantos, G.; Williams, C.; Ararso, Y.; Huang, Y.; Rodrigues, G.; Shen, T. L.; Labori, K. J.; Lothe, I. M.; Kure, E. H.; Hernandez, J.; Doussot, A.; Ebbesen, S. H.; Grandgenett, P. M.; Hollingsworth, M. A.; Jain, M.; Mallya, K.; Batra, S. K.; Jarnagin, W. R.; Schwartz, R. E.; Matei, I.; Peinado, H.; Stanger, B. Z.; Bromberg, J.; Lyden, D., Pancreatic cancer exosomes initiate pre-metastatic niche formation in the liver. Nat. Cell Biol. 2015, 17, 816-826.

(15) Imjeti, N. S.; Menck, K.; Egea-Jimenez, A. L.; Lecointre, C.; Lembo, F.; Bouguenina, H.; Badache, A.; Ghossoub, R.; David, G.; Roche, S.; Zimmermann, P., Syntenin mediates SRC function in exosomal cell-to-cell communication. Proc. Natl. Acad. Sci. U. S. A. 2017, 114, 12495-12500.

(16) Garrido-Urbani, S.; Garg, P.; Ghossoub, R.; Arnold, R.; Lembo, F.; Sundell, G. N.; Kim, P. M.; Lopez, M.; Zimmermann, P.; Sidhu, S. S.; Ivarsson, Y., Proteomic peptide phage display uncovers novel interactions of the PDZ1-2 supramodule of syntenin. FEBS Lett. 2016, 590, 3-12.

(17) Stanzl, E. G.; Trantow, B. M.; Vargas, J. R.; Wender, P. A., Fifteen years of cell-penetrating, guanidinium-rich molecular transporters: basic science, research tools, and clinical applications. Acc. Chem. Res. 2013, 46, 2944-2954.
(18) Lonn, P.; Dowdy, S. F., Cationic PTD/CPP-mediated macromolecular delivery: charging into the cell. Expert Opin. Drug Delivery 2015, 12, 1627-1636.

(19) Green, M.; Loewenstein, P. M., Autonomous functional domains of chemically synthesized human immunodeficiency virus tat trans-activator protein. Cell 1988, 55, 1179-1188.

(20) Songyang, Z.; Fanning, A. S.; Fu, C.; Xu, J.; Marfatia, S. M.; Chishti, A. H.; Crompton, A.; Chan, A. C.; Anderson, J. M.; Cantley, L. C., Recognition of unique carboxyl-terminal motifs by distinct PDZ domains. Science 1997, 275, 73-77.

(21) Stiffler, M. A.; Chen, J. R.; Grantcharova, V. P.; Lei, Y.; Fuchs, D.; Allen, J. E.; Zaslavskaia, L. A.; MacBeath, G., PDZ domain binding selectivity is optimized across the mouse proteome. Science 2007, 317, 364-369.

(22) Tonikian, R.; Zhang, Y.; Sazinsky, S. L.; Currell, B.; Yeh, J. H.; Reva, B.; Held, H. A.; Appleton, B. A.; Evangelista, M.; Wu, Y.; Xin, X.; Chan, A. C.; Seshagiri, S.; Lasky, L. A.; Sander, C.; Boone, C.; Bader, G. D.; Sidhu, S. S., A specificity map for the PDZ domain family. PLoS Biol. 2008, 6, e239.

(23) Powers, E. T.; Deechongkit, S.; Kelly, J. W., Backbonebackbone H-bonds make context-dependent contributions to protein folding kinetics and thermodynamics: lessons from amide-to-ester mutations. Adv. Protein Chem. 2005, 72, 39-78.

(24) Vincentelli, R.; Luck, K.; Poirson, J.; Polanowska, J.; Abdat, J.; Blemont, M.; Turchetto, J.; Iv, F.; Ricquier, K.; Straub, M. L.; Forster, A.; Cassonnet, P.; Borg, J. P.; Jacob, Y.; Masson, M.; Nomine, Y.; Reboul, J.; Wolff, N.; Charbonnier, S.; Trave, G., Quantifying domain-ligand affinities and specificities by high-throughput holdup assay. Nat. Methods 2015, 12, 787-793.

(25) Scott, D. E.; Bayly, A. R.; Abell, C.; Skidmore, J., Small molecules, big targets: drug discovery faces the protein-protein interaction challenge. Nat. Rev. Drug Discovery 2016, 15, 533550.

(26) Wegner, C. S.; Malerod, L.; Pedersen, N. M.; Progida, C.; Bakke, O.; Stenmark, H.; Brech, A., Ultrastructural characterization of giant endosomes induced by GTPasedeficient Rab5. Histochem. Cell Biol. 2010, 133, 41-55.

(27) Nagel, Y. A.; Raschle, P. S.; Wennemers, H., Effect of Preorganized Charge-Display on the Cell-Penetrating Properties of Cationic Peptides. Angew. Chem. Int. Ed. Engl. 2017, 56, 122-126.

(28) Nischan, N.; Herce, H. D.; Natale, F.; Bohlke, N.; Budisa, N.; Cardoso, M. C.; Hackenberger, C. P., Covalent attachment of cyclic TAT peptides to GFP results in protein delivery into live cells with immediate bioavailability. Angew. Chem. Int. Ed. Engl. 2015, 54, 1950-1953.

(29) Rasmussen, R. D.; Gajjar, M. K.; Tuckova, L.; Jensen, K. E.; Maya-Mendoza, A.; Holst, C. B.; Mollgaard, K.; Rasmussen, J. S.; Brennum, J.; Bartek, J., Jr.; Syrucek, M.; Sedlakova, E.; Andersen, K. K.; Frederiksen, M. H.; Bartek, J.; Hamerlik, P., BRCA1-regulated RRM2 expression protects glioblastoma cells from endogenous replication stress and promotes tumorigenicity. Nat. Commun. 2016, 7, 13398.

(30) Yang, Y.; Hong, Q.; Shi, P.; Liu, Z.; Luo, J.; Shao, Z., Elevated expression of syntenin in breast cancer is correlated with lymph node metastasis and poor patient survival. Breast Cancer Res. 2013, 15, R50.

(31) Gangemi, R.; Mirisola, V.; Barisione, G.; Fabbi, M.; Brizzolara, A.; Lanza, F.; Mosci, C.; Salvi, S.; Gualco, M.; Truini, M.; Angelini, G.; Boccardo, S.; Cilli, M.; Airoldi, I.; Queirolo, P.; Jager, M. J.; Daga, A.; Pfeffer, U.; Ferrini, S., Mda-9/syntenin is expressed in uveal melanoma and correlates with metastatic progression. PLoS One 2012, 7, e29989.

(32) Liu, J.; Qu, J.; Zhou, W.; Huang, Y.; Jia, L.; Huang, X.; Qian, Z.; Xia, J.; Yu, Y., Syntenin-targeted peptide blocker 
inhibits progression of cancer cells. Eur. J. Med. Chem. 2018, 154, 354-366.

(33) Kegelman, T. P.; Wu, B.; Das, S. K.; Talukdar, S.; Beckta, J. M.; Hu, B.; Emdad, L.; Valerie, K.; Sarkar, D.; Furnari, F. B.; Cavenee, W. K.; Wei, J.; Purves, A.; De, S. K.; Pellecchia, M.; Fisher, P. B., Inhibition of radiation-induced glioblastoma invasion by genetic and pharmacological targeting of MDA9/Syntenin. Proc. Natl. Acad. Sci. U. S. A. 2017, 114, 370-375.

(34) Grandy, D.; Shan, J.; Zhang, X.; Rao, S.; Akunuru, S.; Li, H.; Zhang, Y.; Alpatov, I.; Zhang, X. A.; Lang, R. A.; Shi, D. L.; Zheng, J. J., Discovery and characterization of a small molecule inhibitor of the PDZ domain of dishevelled. J. Biol. Chem. 2009, 284, 16256-16263.

(35) Thorsen, T. S.; Madsen, K. L.; Rebola, N.; Rathje, M.; Anggono, V.; Bach, A.; Moreira, I. S.; Stuhr-Hansen, N.; Dyhring, T.; Peters, D.; Beuming, T.; Huganir, R.; Weinstein, H.; Mulle, C.; Stromgaard, K.; Ronn, L. C.; Gether, U., Identification of a small-molecule inhibitor of the PICK1 PDZ domain that inhibits hippocampal LTP and LTD. Proc. Natl. Acad. Sci. U. S. A. 2010, 107, 413-418.

(36) Hill, M. D.; Martin, R. H.; Mikulis, D.; Wong, J. H.; Silver, F. L.; Terbrugge, K. G.; Milot, G.; Clark, W. M.; Macdonald, R. L.; Kelly, M. E.; Boulton, M.; Fleetwood, I.; McDougall, C.; Gunnarsson, T.; Chow, M.; Lum, C.; Dodd, R.; Poublanc, J.; Krings, T.; Demchuk, A. M.; Goyal, M.; Anderson, R.; Bishop, J.; Garman, D.; Tymianski, M.; investigators, E. t., Safety and efficacy of NA-1 in patients with iatrogenic stroke after endovascular aneurysm repair (ENACT): a phase 2, randomised, double-blind, placebo-controlled trial. Lancet Neurol. 2012, 11, 942-950.

(37) Bach, A.; Clausen, B. H.; Moller, M.; Vestergaard, B.; Chi, C. N.; Round, A.; Sorensen, P. L.; Nissen, K. B.; Kastrup, J. S.; Gajhede, M.; Jemth, P.; Kristensen, A. S.; Lundstrom, P.; Lambertsen, K. L.; Stromgaard, K., A high-affinity, dimeric inhibitor of PSD-95 bivalently interacts with PDZ1-2 and protects against ischemic brain damage. Proc. Natl. Acad. Sci. U. S. A. 2012, 109, 3317-3322.

(38) Doyle, D. A.; Lee, A.; Lewis, J.; Kim, E.; Sheng, M.; MacKinnon, R., Crystal structures of a complexed and peptidefree membrane protein-binding domain: molecular basis of peptide recognition by PDZ. Cell 1996, 85, 1067-1076.

(39) Eildal, J. N.; Hultqvist, G.; Balle, T.; Stuhr-Hansen, N.; Padrah, S.; Gianni, S.; Stromgaard, K.; Jemth, P., Probing the role of backbone hydrogen bonds in protein-peptide interactions by amide-to-ester mutations. J. Am. Chem. Soc. 2013, 135, 12998-13007.

(40) Pedersen, S. W.; Pedersen, S. B.; Anker, L.; Hultqvist, G.; Kristensen, A. S.; Jemth, P.; Stromgaard, K., Probing backbone hydrogen bonding in PDZ/ligand interactions by protein amideto-ester mutations. Nat. Commun. 2014, 5, 3215.

(41) Grembecka, J.; Cierpicki, T.; Devedjiev, Y.; Derewenda, U.; Kang, B. S.; Bushweller, J. H.; Derewenda, Z. S., The binding of the PDZ tandem of syntenin to target proteins. Biochemistry 2006, 45, 3674-3683.

(42) Suckfuell, M.; Lisowska, G.; Domka, W.; Kabacinska, A.; Morawski, K.; Bodlaj, R.; Klimak, P.; Kostrica, R.; Meyer, T., Efficacy and safety of AM-111 in the treatment of acute sensorineural hearing loss: a double-blind, randomized, placebocontrolled phase II study. Otol. Neurotol. 2014, 35, 1317-1326.

(43) Craik, D. J.; Fairlie, D. P.; Liras, S.; Price, D., The future of peptide-based drugs. Chem. Biol. Drug Des. 2013, 81, 136-147.

(44) Simeonova, I.; Huillard, E., In vivo models of brain tumors: roles of genetically engineered mouse models in understanding tumor biology and use in preclinical studies. Cell. Mol. Life Sci. 2014, 71, 4007-4026.

(45) Egea-Jimenez, A. L.; Gallardo, R.; Garcia-Pino, A.; Ivarsson, Y.; Wawrzyniak, A. M.; Kashyap, R.; Loris, R.;
Schymkowitz, J.; Rousseau, F.; Zimmermann, P., Frizzled 7 and PIP2 binding by syntenin PDZ2 domain supports Frizzled 7 trafficking and signalling. Nat Commun 2016, 7, 12101.

(46) Vincentelli, R.; Luck, K.; Poirson, J.; Polanowska, J.; Abdat, J.; Blemont, M.; Turchetto, J.; Iv, F.; Ricquier, K.; Straub, M. L.; Forster, A.; Cassonnet, P.; Borg, J. P.; Jacob, Y.; Masson, M.; Nomine, Y.; Reboul, J.; Wolff, N.; Charbonnier, S.; Trave, G., Quantifying domain-ligand affinities and specificities by high-throughput holdup assay. Nat. Methods 2015, 12, 787-793.

(47) Otwinowski, Z.; Minor, W., Processing of X-ray diffraction data collected in oscillation mode. Methods Enzymol 1997, 276, 307-326.

(48) Emsley, P.; Lohkamp, B.; Scott, W. G.; Cowtan, K., Features and development of Coot. Acta Crystallogr D. Biol. Crystallogr 2010, 66, 486-501.

(49) Adams, P. D.; Afonine, P. V.; Bunkoczi, G.; Chen, V. B.; Davis, I. W.; Echols, N.; Headd, J. J.; Hung, L. W.; Kapral, G. J.; Grosse-Kunstleve, R. W.; McCoy, A. J.; Moriarty, N. W.; Oeffner, R.; Read, R. J.; Richardson, D. C.; Richardson, J. S.; Terwilliger, T. C.; Zwart, P. H., PHENIX: a comprehensive Python-based system for macromolecular structure solution. Acta Crystallogr D. Biol. Crystallogr 2010, 66, 213-221.

(50) Hanssen, K. O.; Andersen, J. H.; Stiberg, T.; Engh, R. A.; Svenson, J.; Geneviere, A. M.; Hansen, E., Antitumoral and mechanistic studies of ianthelline isolated from the Arctic sponge Stryphnus fortis. Anticancer Res 2012, 32, 4287-4297.

(51) Ghossoub, R.; Lembo, F.; Rubio, A.; Gaillard, C. B.; Bouchet, J.; Vitale, N.; Slavik, J.; Machala, M.; Zimmermann, P., Syntenin-ALIX exosome biogenesis and budding into multivesicular bodies are controlled by ARF6 and PLD2. Nat. Commun. 2014, 5, 3477. 


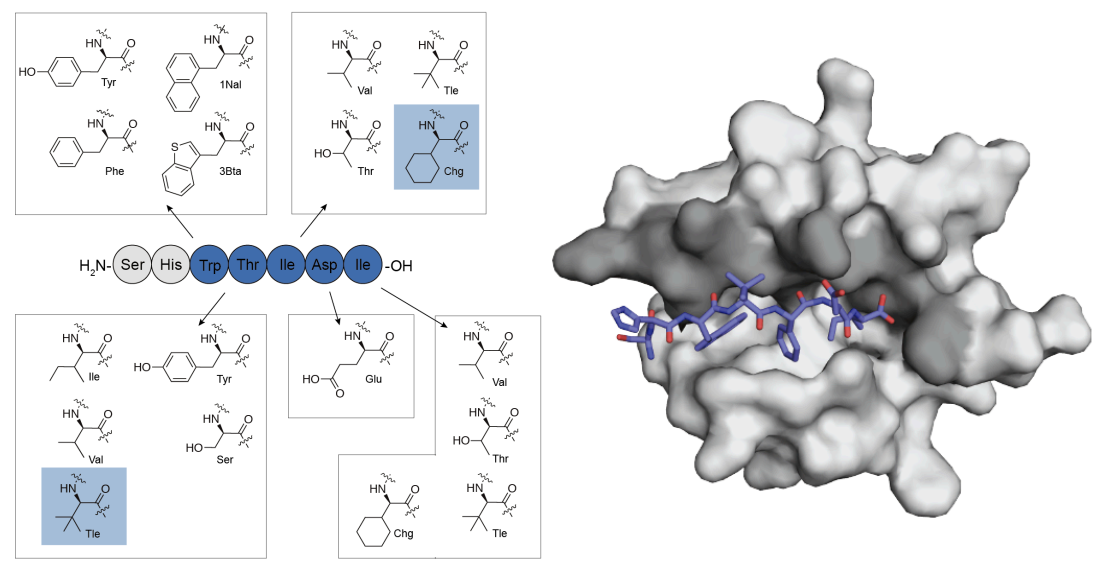

TOC graphic (111.8 mm x $56.6 \mathrm{~mm})$ 